American Journal of Economics and Business Administration 2 (3): 280-286, 2010

ISSN 1945-5488

(C) 2010 Science Publications

\title{
Guerrilla Marketing Communication Tools and Ethical Problems in Guerilla Advertising
}

\author{
${ }^{1}$ Canan Ay, ${ }^{2}$ Pinar Aytekin and ${ }^{3}$ Sinan Nardali \\ ${ }^{1}$ Department of Business Administration, Faculty of Economics and Administrative Science, \\ Celal Bayar University, Manisa, Turkey \\ ${ }^{2}$ Department of Marketing, Turgutlu Occupational College, Manisa, Turkey \\ ${ }^{3}$ Department of International Trade, School of Applied Science, Manisa, Turkey
}

\begin{abstract}
Problem statement: Companies attempt to reach private worlds of consumers and give them memorable experience with their brands by using guerrilla marketing tools. Guerrilla advertising, which is one of the guerrilla marketing tools, usually attracts the attention of consumers but sometimes irritates and annoys the consumers and even breaks the law. Approach: The study determined these ethical aspects by evaluating different guerilla advertising strategies of the companies. A critical assessment of the printed and visual discoursed of guerilla ads were made in this context. Results: The assessment indicated that there are some ethical problems about guerrilla advertising implementations. Especially the ads, which include fear-appeal, may irritate people. Also, distraction of attention in traffic is the other important ethical problem. Conclusion/Recommendations: These kinds of guerrilla ads may reduce the effectiveness of advertisements in general and dislike of a company's ad may lead to biased reactions towards future advertisements. Ethical, legal and societal boundaries must be considered in guerilla advertising strategies. In sum today's marketers have to take greater responsibility for the negative impacts of the practices of guerilla advertising.
\end{abstract}

Key words: Marketing communication, guerrilla advertising, ethical problems

\section{INTRODUCTION}

Uncertainty, brought about by changes associated with globalization, makes it necessary for businesses to produce more and react to changes more quickly. However, many large companies, today, carry on their activities by means of traditional marketing strategies. The managers of these companies plan their marketing policies by analyzing research done by their own company or other market research companies. The product and brand managers of these businesses also lack the creativity and passion of guerilla marketers. At this point, these managers should leave their offices and spend time with their prospects in order to create new values for their lives and they should find new ways to do so as quickly as possible (Kotler, 2003). Such dynamism, while making it possible to respond to changes in the market quickly, also makes it necessary that companies adopt original strategies that are based on their primary abilities and advantages. This necessity has made it almost inescapable for companies to employ unconventional marketing strategies such as guerilla marketing. Guerilla marketing, which consists of strategies that can be applied by businesses easily and with little cost, is an important marketing tool that companies should learn and make use of in order to be successful in such a competitive environment.

The guerrilla marketing concept, which was created by Levinson (1984), implies an unconventional way of performing promotional activities on a very low budget. In recent years, many companies, looking for ways of getting out of clutter of traditional marketing implementations, tend to apply guerrilla marketing which is a different way of marketing communication. Not only the effect of guerilla marketing strategies is important, but also the direction and the intensity of the effects are also crucial. According to Rossiter and Percy (1987) the message and the theme should take social and individual values into account. When the message and theme are coded correctly, positive reactions develop, but in those cases in which the message is coded and directed in a wrong way, the communicative effect of the advertisement is usually negative (Firlar, 2005). That is why, despite the unrestricted creative applications, ethical, legal and societal boundaries must be preserved in guerilla marketing strategies. In this sense, there must be a boundary between the creative

Corresponding Author: Canan Ay, Department of Business Administration, Faculty of Economics and Administrative Science, Celal Bayar University, Manisa, Turkey Tel: 902362330949 Fax: 902362336132 
strategies of guerilla marketing and its irresponsibly developed applications (Zuo and Veil, 2006; Levinson and Rubin, 1996; Wilson et al., 1992).

Guerilla marketing: Guerilla marketing is a tool that allows SME's to demoralize their rivals with small, periodical and surprising attacks, requires swift action and utilizes creativity and imagination (Tek, 1999). Through guerilla marketing, businesses aim at forming a marketing management that is dynamic, sensitive to customer needs and that is able to adapt to changes easily. Today, the increasing variety of products and services as well as their similarity negatively affect business profits.

On the other hand, economic uncertainty, brought about by constant changes, has made it necessary to reconsider the costs of marketing activities making up a substantial portion of firms' budgets. As a response, firms have been seeking to find different, novel, effective and less costly marketing strategies. In such a context, although it resembles traditional marketing, guerilla marketing differs from such conventional approaches in terms of the ways used to reach ends and techniques that are employed and offers many advantages to those who execute it. Gallagher (2004) explains this difference as: "What matters in guerilla marketing is, rather than what the firm does to be successful but what it does to differentiate itself from its rivals and its success in reaching a broader customer potential".

Guerilla marketing and marketing communication tools: Currently, costs of promotion in sales are on the rise. Despite the fact that businesses spend more money on promotions, they cannot guarantee effectiveness either. The most important reason for that is the media crowd caused by new businesses that resort to promotions and advertisements to introduce their products and services to their target customers and the old businesses that increase their already existing advertising and promotional activities in an effort to compete with the new businesses. At this point, the first action to be taken by the guerilla marketer is to overcome this media crowd without increasing the costs of promotion in sales and second, increase the firm's profits not through direct sales parameters such as costpromotion-discount but by creating a difference in the perception of the study and the product.

Marketing communication tools (such as advertising, personal selling, sales promotion and public relations) play an important role in increasing the volume and quality of communications of the businesses with their customers. Innovative implementations by guerilla marketers provide important advantages to the businesses. However, guerilla marketing strategies that are developed without considering certain principles and especially guerilla ads cause important ethical problems. This affects the marketing efforts of businesses in a negative way.

This study, first discusses marketing communication tools (advertising, personal selling, sales promotion and public relations) and guerilla marketing strategies and elaborates on ethical problems related to guerilla advertising. Then, some of the high profile guerilla ads examples will be evaluated.

Guerilla advertising strategies: The innovative and entrepreneurial spirit of guerilla marketers is mostly observed in the advertising activities of companies. Through the use of various media, tools and slogans, the guerilla marketer both differentiates the company's ads from those of its rivals to a great extent and positions its products and services distinctly in the minds of the prospects. The differentiation created by the positioning of the ad's message in the prospect's mind not only communicates its message but also ensures that the message is imprinted for a longer period. This plays an important role in the effectiveness of the ad.

The person who is responsible from the advertising activities of the company following a guerilla marketing strategy should possess the ability to realize the company's vision. Levinson (1998), who introduced guerilla marketing concept, stressed the importance of the following principles for the advertising activities of the companies that use guerilla marketing strategies:

- By being as specific as possible, these advertisements should be persuasive and directly contribute to the company's profits

- In the case of an ad that includes a witness, the witness should be a real customer and the ad should refer to real events and real names

- The realistic goals should be communicated to the target customers in a creative way

Adhering to these principles when developing the advertising activities enables the company that employs guerilla marketing strategy to increase its ad's effectiveness, gain new customers and increase its profits. Apart from these principles, the ethical aspect of such ads should also be taken into consideration.

Guerilla personal selling strategies: Personal selling is a process in which a salesperson engages in face-toface marketing in an effort to direct the existing and the potential customers to the products and/or services of 
the company that she represents. Meetings with the customers, informational presentations at such meetings and small gifts and presents that are intended to increase participation in and effectiveness of such activities are among the most important tools of this process (Kotler, 2005). Personal selling is crucial for companies to establish long-term and continuous relations with their customers.

To be able to successfully apply guerilla marketing, companies need guerillas (salespersons) that would invest all their time and energy to the marketing activities of the company. Personal selling is particularly important for guerilla marketing since the salesperson is the public face of the company and first point of contact. Guerillas can be recruited either from within the company or from outside sources when needed. For companies that are planning to employ guerilla marketing strategies, training guerillas is the most important step of the strategy.

The sincerity of the guerillas towards their customers in all matters, their entrepreneurial spirit and their intense efforts and disciplined work to provide solutions to the problems in their field leads to increased customer loyalty as the customers would not want to go anywhere else. The study itself is what motivates the guerilla in the first place. Being chosen by their customers is a reward for the guerilla. That is why; the reward of the guerilla is to satisfy the needs of more customers by engaging in business with more of them. The trust towards guerilla and her company is the guarantee of the sales that the company will make to these prospects (Levinson, 1994).

Guerilla public relations strategies: International Public Relations Association defines public relations as the continuous activities of public or private organizations in order to maintain the recognition, sympathy and the support of the people that the organization may have contact with. Based on this definition, we may say that public relations has three objectives: Providing comprehensive information about an activity, maintaining positive personal relations within the establishment and establishing an effective communication network (Budak and Budak, 1998). These are also the targets of the guerilla marketing process. Such that, guerillas are those people who are aware that they could increase their profits by engaging in better relations with target customers and by producing more value for them. Public relations is the main instrument both for getting to know prospects who are at the core of unconventional marketing approaches and for being able to produce economic worth for them as effectively as possible. Guerillas, by using these activities to get in touch with more consumers and in engaging in better relations with them aim at increasing the profits. From this perspective, the foremost duty of the guerilla is to understand the characteristics and the desires of the society and the prospect he/she is in relation with and to communicate the policies and the practices she follows to the public using various communication tools.

A smart guerilla marketer pays special attention to public relations. In case the business have been earning profits from its customers for some time, there is no harm in paying part of the profits back to the customers through public relations activities such as sponsorships (Levinson, 1998).

An important part of public relations activities that the managements carry out is the efforts by the businesses to engage in efforts to provide solutions to the common problems of the society. The fact that the businesses want to engage in public relations activities is not enough by itself. For such efforts to be successful and effective, companies need innovative and entrepreneurial ideas of the guerillas.

Guerilla sales promotion strategies: Sales promotion consists of sales promotion tools such as exhibitions, premiums to salespersons, discounts and competitions in an effort to encourage prospects to buy and to increase the effectiveness of the intermediators. Through the use of these tactics, businesses aim at getting customers to take immediate action. Within the scope of integrated marketing, whereas advertising increases the effectiveness of sales promotion, personal selling and public relations support these efforts to a great extent (Kotler, 2005).

Advertising specials and free gifts distributed in the process of sales promotion have a special place in guerilla marketing. Especially in markets where competition is intense and where it is hard to attract the attention of the consumers, sales promotion tools are used more frequently. In such cases, free gifts distributed by businesses affect all demographic groups to a great extent. Research on sales promotion shows that $40 \%$ of those who were given gifts remember the company name for at least 6 month sand $31 \%$ up to 1 year. According to a recent research, free gifts, due to increased interest on part of the customers, also lead to an increase in sales revenues (Ay and Unal, 2002). In addition, the fact that these gifts naturally lead to positive feelings among consumers is reflected not only in sales but also in the close relations of the company with customers. Guerillas aim at increasing the number of interactions with the customers and their sales through the help of these sales promotion tools (Levinson, 2009). 
Ethical problems of guerilla advertising strategies: Although there are successful applications of guerilla marketing strategies and related advertisements, guerilla advertising activities that are not developed and executed properly may lead to certain ethical problems. Especially those advertisements that embrace fearappeals irritate the target consumers or those that are distracting may be ethically problematic.

Contemporary advertisements aim at arousing the viewer's emotions. Advertisers try to arouse emotions for three purposes (Higbee, 1969):

- Emotions per se are an important benefit derived from a product or brand

- Emotions may help to communicate the benefits of a product or brand

- Emotions can directly affect attitudes

As effective as emotion-arousing advertisement might be, its improper use may have side-effects. Hyman and Tansey (1990) refer to those emotionarousing ads that cause a group of viewers to feel extremely anxious, hostile toward others or feel a loss of self-esteem as psychoactive ads. The planning of advertising without taking into consideration such facts may lead to certain ethical problems. In such ads, the advertiser may target a specific result, or may aim at increasing product sales. Whatever the goal is, it affects and draws the attention of the audience. Such ads do not aim at entertaining the audience. They make the audience feel angry, disturbed, fearful and sad (Hyman and Tansey, 1990). Such irritating ads provoke the viewers and lead to discontent and temporary impatience. The emotions aroused are in fact worse than dislike (Aaker and Bruzzone, 1985). The aim is to evoke negative emotions such as fear or sadness rather than positive feelings of happiness, peace, or love. These factors that irritate the viewers or consumers may lead to the development of negative attitudes towards the brand.

Some research discusses the irritation caused by the fear appeal of some ads and examines their ethical aspect. According to Duke et al. (1993) and LaTour and Zahra (1989), the use of fear appeals leads to negative, unwanted reactions on individual consumers. Higbee (1969) argues that too much fear-appeal leads to anxiety disorders. On the other hand, as mentioned above, fear appeals in advertisements also attract attention and intensify the persuasive power of the ad. Higbee (1969) and LaTour and Pitts (1989) find that powerful fear appeals in health and security-related products are more effective than weak fear appeals (Snipes et al., 1999). However, it is also crucial to decide on the right amount of fear-appeal to be used. The effectiveness of fear appeal depends more on the probability and reality of the fear rather than its extensive intensity.

The process of the use of fear appeals in advertising has three steps. The first step consists of the design of a fearful situation in order to evoke risk perceptions and vulnerability of the individual. Marketers are in fact quite brilliant in doing this and there are interesting examples of such ads in which the fear appeal is cleverly used. The second step involves the illustration of the danger in an effort to guarantee attention. Solution is presented by alleviating the fear in the third step. Accordingly, a connection is established between fear and assurance of "protection from fear" in order to convince customers to view the recommended action. Leventhal (1970) and LaTour and Zahra (1989) presents this process in Fig. 1.

As can be seen in the Fig. 1, emotional response follows the fear stimulant, which leads to stress. This stress leads individual to watch the recommended action. In case the recommended action is sufficient in reducing the fear and the stress, it leads to relief. This means "there is no fear". In this case, the process is completed. However, in case of failure to reduce fear, it could be possible for the danger to be denied or be ignored. This means that the process continues due to new reaction.

Some authors have argued that increase in the number of ads with fear appeals may reduce the effectiveness of advertisements in general. For example, according to Greyser (1973), public dislike of the ad leads to the erosion of the goodwill on which public receptivity to it depends. In addition, public dislike of advertisement specific to a company may reduce the short-term and particularly, the long term effectiveness of that ad (Gallagher, 2004). At the same time, dislike of the company's ad may lead to biased reactions towards future advertisements.

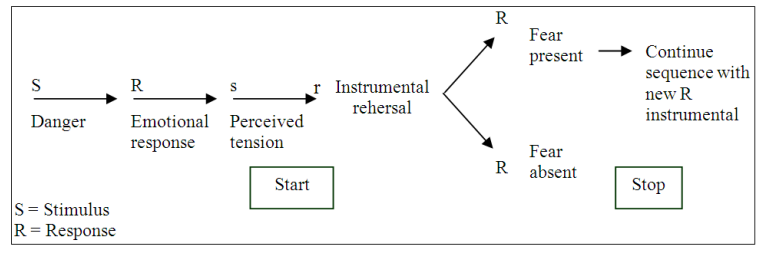

Fig. 1: The fear drive model. Source: Leventhal (1970) 
Other ethical problems of guerilla marketing include the trespassing on private property, defacing private or public property and not getting permission from the property owners. Curran and Seaton (1997) has argued that placing Burger King stickers on bus schedules to indicate store locations may be considered an act of vandalism (Zuo and Veil, 2006). Pictures or pamphlets placed illegally on other places (public buses, bus stops, building walls) also point out to the same problem.

Guerilla marketing may include some dangers. For example, ads placed in the middle of the road may distract the drivers, thus causing traffic accidents (Zuo and Veil, 2006). In addition, guerilla ads placed on public buses, cabs, or private vehicles, both because of their content and their design carry the risk of traffic accidents by jeopardizing the traffic flow.

\section{MATERIALS AND METHODS}

In this study, a critical assessment of the printed and visual discourses of guerilla ads is made. For this part of the study, first an internet search of guerilla ads were carried out and then, five examples that are believed to be ethically problematic were chosen. These five examples are presented below.

D.D. Dirin (pesticide firm): In a guerilla ad for an exterminator company called D.D. Dirin, a fake cockroach is placed through the houses' doors. The person who enters the house sees the roach and attempts at killing it, but realizes that the insect is not alive. When the cockroach is turned upside down, it is seen that it is nothing more than a brochure. The brochure includes a short note about how easy it is for the insects to get inside the houses and together with the name and the contact information of the company.

24 (serialized film): Channel 2 in Belgium executed a guerilla campaign for the TV series 24 , which is also broadcast in Turkey in Cnbc-E and has a lot of fans. The poster that was prepared for the campaign shows scenes of traffic pull over in the city center of Antwerp, creating the sense that there is a biological danger. In the poster, there are pictures of men with masks and special uniforms distributing flyers that state the presence of a deadly virus. In these flyers, after the word "Caution" comes the statement: "There is a fatal virus in the city. Go home now; close your windows and doors. Turn on your television". Under the flyer, there is the logo of the TV channel and the series 24 .
Perlodent (toothpaste): In a toothpaste ad that is attached to the bottle opener apparatus of the Coca Cola vending machine a woman opening the bottle with her strong and white teeth is displayed. When a customer uses the bottle opener part of the vending machine it is the woman with her white teeth that opens the bottle, thus the advertisement aims at giving the impression that the toothpaste is very effective.

Kill Bill (movie): In this guerilla advertisement that was used in the washroom of a movie theatre, there is a shocking image seen from the outside the toilet cabin. In the image there is blood leaking from under the door of the cabin. But when the door is opened it is realized that this is a sticker that shows the release date of the movie "Kill Bill".

Pringles (potato chips): In this guerilla type ad, a fake potato chip is placed on the wiper of the back window of a cab. On the right side of this window, there is the picture of a man and a Pringles box is placed on the left side. Every time the wiper is turned on, it moves from left to right, thus leading to the impression that the potato chip that goes out of the Pringles box goes into the mouth of the men in the picture.

\section{RESULTS}

D.D. Dirin advertisement is not only inventive and catchy but also irritating because the feelings of disgust it evokes in the prospects.

In terms of ethical terms, we may say that fearappeal is used intensely in serialized film 24. Both the uniforms and the masks and the warning text reflect a fatal danger and this leads to anxiety and misunderstanding.

In Perlodent ad, on which the brand name and logo also displayed, is ethically questionable especially for the potential effects it can have on children. It is not hard to imagine the negative consequences of the ad on children especially when we consider the fact that kids usually imitate the behaviors they find interesting. In the absence of a parent or a guard, the kid may attempt at opening such metal lids, which may lead to serious injuries.

It is possible to argue that the horrifying fearappeal used in Kill Bill study is ethically problematic. The images used in this ad may have negative consequences for the viewers. Especially if the person that is exposed to these scenes is a kid, this may cause psychological problems and even end up the kid not being able to go to the restroom alone. 
In Pringles ad, it is highly likely for the driver that is behind the cab to be distracted when going through the traffic. This ad which may lead to accidents is just as ethically problematic as the others.

\section{DISCUSSION}

As previously mentioned, nature of guerilla advertising brings the ethicality of some practice into question. Guerrilla ads that use extensive fear-appeal may cause irritation and lead to anxiety disorder in consumers. Assessment of the ads above indicated that 24, D.D. Dirin and Kill Bill examples used this appeal. Apart from causing ethical problems, such guerilla advertising strategies that irritate prospects may also lead to the development of negative attitudes towards the brand.

Guerilla advertising even carries some dangers. For instance, ads placed in the middle of the road or on public buses, cabs, or private vehicles (as in the case of the Pringles ad) may cause traffic accidents as it distracts the drivers. Their content and design may carry the risk of jeopardizing the traffic.

Guerilla advertisement sometimes may have a negative effect on children. Behavior imitations like opening metal lids by teeth, which is mentioned in Perlodent ad, may be a problem for kids as it may cause tooth or mouth injuries. Therefore, firms should add a caution note at the bottom of the poster to warn the kids not to try the same thing.

Trespassing on private or public property without getting permission is the other ethical problem of guerrilla advertising. Placing pictures or flyers illegally on public buses, bus stops, building walls etc. indicates this problem.

As it can be understood from the discussion of the subject and the examples presented, a boundary must be maintained between creative strategies of guerilla marketing and their irresponsible applications. Despite the unrestrained nature of guerilla activities, ethical, legal and social boundaries must be achieved.

In order to obtain more effective and generalizable results, future studies should address the ethical problems caused by other guerilla marketing tools instead of guerrilla advertising. Different types of guerilla marketing applications and the ethical problems they cause should be demonstrated using concrete examples and data.

\section{CONCLUSION}

The goal of guerilla ad is to increase customer awareness and interest through the product and its associated brand. Acceptability of a guerilla ad is related to its ends rather than its means. Although there are successful examples of guerilla marketing strategies, some of guerilla advertising implementations that are prepared and executed without certain boundaries may lead to ethical problems. Those ads, which include fear-appeal, irritate the prospects and distract attention, may be problematic in ethical terms.

It is argued that the use of extensive fear-appeal may reduce the effectiveness of advertisements in general. Public dislike of an ad may lead to the erosion of the goodwill and may reduce the short-term and particularly, the long term effectiveness of that advertisement. At the same time, dislike of a company's ad may have negative effects on future advertisements. Firms should continue to search for creative ways to connect with their customers, but they have to implement these new strategies in a more responsible manner because the ethicality of guerilla ad is measured by its consequences.

\section{REFERENCES}

Aaker, D.A. and D.E. Bruzzone, 1985. Causes of irritation in advertising. J. Market., 49: 47-57. http://www.jstor.org/stable/1251564

Ay, C. and A. Unal, 2002. New marketing approach for SMEs: Guerilla marketing. J. Manage. Econ., 9: 75-85.

http://www.bayar.edu.tr/ iibf/dergi/pdf/C9S1_220 02/caau.pdf

Budak, G. and G. Budak, 1998. A Behavioral. Approach to Public Relations. 2th Edn., Baris Basimevi, Turkey, ISBN: 975-486-474-8, pp: 247.

Curran, J. and J. Seaton, 1997. Power without Responsibility: Press and Broadcasting in Britain. 5th Edn., Routledge, USA., ISBN: 0-415-24390-4, pp: 432.

Duke, C.R., G.M. Pickett, L. Carlson and S.J. Grove, 1993. A method for evaluating the ethics of fear appeals. J. Public Policy Market, 1: 120-129. http://www.jstor.org/stable/30000117

Firlar, B.G., 2005. Millennium advertisements in Turkey: A study for determining Aegean University youth's attitudes towards impulsive advertising theme. Bilig, 33: 23-43. http://www.yesevi. edu.tr/bilig/biligTur/pdf/33/2343.pdf

Gallagher, B., 2004. Guerilla marketing and branding. MarketingTurkiye.

http://www.marketingturkiye.com/yeni/Soylesiler/ Soylesi_Detay.aspx?id=28 
Greyser, S.A., 1973. Irritation in advertising. J. Advert. Res., 13: 3-10.

Higbee, K.L., 1969. Fifteen years of fear arousal: Research on threat appeals: 1953-1968. Psychol. Bull, 72: 426-444.

Hyman, M.R. and R. Tansey, 1990. The ethics of psychoactive ads. J. Bus. Eth., 9: 105-114.

Kotler, P., 2003. Marketing Management. 11th Edn., Pearson Education Inc., CA., ISBN: 81-7808-6549, pp: 655.

Kotler, P., 2005. New Marketing Lessons. 1st Edn., Cem Ofset, pp: 140.

LaTour, M.S. and R.E. Pitts, 1989. Using fear appeals in advertising for AIDS prevention in the collegeage population. J. Health Care Market, 9: 5-14. http://www.jstor.org/stable/30000117

LaTour, M.S. and S.A. Zahra, 1989. Fear appeals as advertising strategy: Should they be used. J. Consum. Market., 6: 61-70. DOI: 10.1108/EUM0000000002548

Leventhal, H., 1970. Findings and theory in the study of fear communications. Adv. Exp. Soc. Psychol., 5: 119-186. DOI: 10.1016/S0065-2601(08)60091-X

Levinson, J.C., 1984. Guerilla Marketing: How to Make Big Profits in Your Small Business. 1th Edn., Houghton Mifflin, USA., ISBN: 0-395-38314-5, pp: 226.

Levinson, J.C., 1994. Guerilla Advertising: CostEffective Techniques for Small-Business Success. 1st Edn., Houghton Mifflin Company, USA., ISBN: 10: 0395687187, pp: 304.
Levinson, J.C., 1998. Guerilla Marketing. 3rd Edn., Mariner Books, USA., ISBN: 13: 9780395906255 , pp: 388.

Levinson, J.C. and C. Rubin, 1996. Guerrilla Marketing-On Line Weapons: 100 Low-Cost, High-Impact Weapons for Online Profits and Prosperity. 1st Edn., Mariner Books, USA., ISBN: 13: 9780395770191, pp: 183.

Levinson, J.C., 2009. Guerilla competitive advantages. Gmarketing. http://gmarketing.com/tactics/weekly19.html

Rossiter, J.R. and L. Percy, 1987. Advertising and Promotion Management. 2nd Edn., McGraw-Hill Inc., USA., ISBN: 13: 9780070539075 , pp: 648.

Snipes, R.L., M.S. LaTour and S.J. Bliss, 1999. A model of the effects of self-efficacy on the perceived ethicality and performance of fear appeals in advertising. J. Bus. Eth., 19: 273-285. http://www.jstor.org/stable/30000117

Tek, O.B., 1999. Principles of Marketing. 8th Edn., Beta Basimevi, Turkey, ISBN: 9754867375, pp: 902.

Wilson, O.R., W.K. Gallagher and J.C. Levinson, 1992. Guerilla Selling: Unconventional Weapons and Tactics for Increasing Your Sales. 1st Edn., Mariner Books, USA., ISBN: 10: 0395578205, pp: 244.

Zuo, L. and S. Veil, 2006. Guerilla Marketing and the aqua teen hunger force fiasco. Public Relat. Quart., 51: $8-11$. 